\title{
PENGARUH KUALITAS LAYANAN DAN PROMOSI TERHADAP KEPUASAN PELANGGAN PT ADHI KARYA, TBK
}

\author{
Firmansyah Sulaeman. $\mathbf{G}^{1)}$ \\ 1) Mahasiswa Program Studi Manajemen FE UNKRIS \\ Devi Krisnawati ${ }^{2}$ ) \\ 2) Dosen Program Studi Manajemen FE UNKRIS \\ Alamat: Kampus UNKRIS, Jatiwaringin Jakarta Timur \\ Email : devikrisnawati@gmail.com
}

\begin{abstract}
To determine the effect of service quality and promotion on customer satisfaction, PT. Adhi Karya, Tbk. The data used are primary data by giving questionnaires to customers who happen to meet. The analytical method used is simple linear regression analysis and multiple linear regression analysis. The results showed that the quality of service and promotion has a significant effect on customer satisfaction. PT. Adhi Karya, Tbk.
\end{abstract}

Keywords: Service quality, promotion and customer satisfaction

\section{PENDAHULUAN}

Perkembangan dunia usaha dewasa ini ditandai dengan makin tajamnya persaingan, khususnya dalam pengelolaan unit usaha perusahaan. Kondisi ini tidak saja dialami perusahaan swasta tapi juga untuk perusahaan pemerintah, karena masing-masing perusahaan mempunyai arah dan tujuan yang sama yaitu mengelola sebuah bisnis yang menguntungkan. Mengingat begitu tinggi resiko yang ditimbulkan dari pengelolaan bisnis, maka perusahaan swasta dan pemerintah mempunyai tujuan untuk memuaskan pelanggan. Adapun cara dalam menciptakan kepuasan pelanggan itu dengan jalan memberikan layanan yang baik dan ramah pada pelanggan, melakukan promosi yang menyakinakan buat pelanggan, karena pelanggan dianggap sebagai raja sehingga perusahaan harus memenuhi segala keinginan pelanggan. Apabila hal ini dapat terwujud, maka dapat dipastikan pelanggan akan merasa puas.
Sehubungan dengan hal tersebut, maka setiap pelaku usaha di tiap kategori bisnis dituntut untuk memiliki kepekaan terhadap setiap perubahan yang terjadi dan menempatakan kepuasan pelanggan sebagai tujuan utama. Perusahaan dalam memberikan kepuasan pada pelanggan harus mempelajari terlebih dahulu keinginan dan kebutuhan pelanggan saat ini dan yang akan datang. Jika kepuasan pelanggan berada dibawah harapan, maka pelanggan tidak puas. Jika kepuasan pelanggan memenuhi harapan, maka pelanggan akan puas. Jika kepuasan pelanggan melebihi harapan, maka pelanggan akan amat puas atau senang. Kunci untuk menghasikan kepuasan pelanggan adalah memberikan nilai pelanggan yang tinggi.

Dengan adanya layanan yang baik tentunya akan meningkatkan kepuasan yang diterima dari produk yang telah terjual. Agar dapat bersaing dan bertahan hidup dan berkembang maka perusahaan dituntut untuk memenuhi kebutuhan dan 
keinginan pelanggan dengan jalan memberikan layanan yang memuaskan bagi pelanggan maka dengan sendirinya pelanggan merasa dihargai dan akan bersedia menjadi pelanggan tetap.

Promosi adalah upaya untuk memberitahukan atau menawarkan produk atau jasa pada dengan tujuan menarik calon konsumen untuk membeli atau mengkonsumsinya. Dengan adanya promosi, produsen atau perusahaan mengharapkan kenaikannya angka penjualan. Promosi yang dilakukan perusahaan akan menciptakan suatu penilaian tersendiri pada pikiran pelanggan sehingga penilaian pelanggan terhadap promosi produk secara langsung maupun tidak langsung akan menciptakan image terhadap suatu produk. Aktivitas promosi merupakan usaha pemasaran yang memberikan berbagai upaya intensif jangka pendek untuk mendorong keinginan mencoba atau membeli suatu produk atau jasa. Seluruh kegiatan promosi bertujuan untuk mempengaruhi perilaku pembelian, tetapi tujuan promosi yang utama adalah memberitahukan, membujuk dan mengingatkan kembali pelanggan terhadap sebuah produk atau jasa.

Salah satu bidang bisnis yang bergerak di bidang konstruksi juga merasakan ketatnya persaingan saat ini. PT Adhi Karya Tbk (ADHI) adalah perusahaan yang bergerak di bidang konstruksi di Indonesia. Perusahaan yang didirikan pada tahun 1960 ini bermarkas di Jakarta, Indonesia. Perusahaan ini awalnya bernama rchitecten-Ingenicureen Annemersbedrijf Associatie Selle en de Bruyn, Reyerse en de Vries N.V. (Associatie N.V.) saat kepemilikikannya masih di bawah Belanda. Namun sejak tanggal 11 Maret 1960, perusahaan di nasionalisasi dengan tujuan untuk memacu pembangunan infrastruktur di Indonesia. Bisnisnya termasuk layanan konstruksi, EPC, investasi infrastruktur, properti, dan real estate.

Dalam kegiatan operasionalnya, ADHI didukung oleh delapan divisi operasi yang tersebar di seluruh Indonesia dan luar negeri di samping Anak-anak Perusahaannya. Perusahaan ini memiliki visi untuk menjadi salah satu Perusahaan konstruksi terkemuka di Asia Tenggara dengan melakukan kinerja berdasarkan atas peningkatan corporate value secara incorporated, melakukan proses pembelajaran (learning) dalam mencapai pertumbuhan (peningkatan corporate value), proaktif melaksanakan lima lini bisnis secara profesional, governance, mendukung pertumbuhan perusahaan, dan menerapkan Corporate Culture yang simple tapi membumi/dilaksanakan (down to earth), serta ikut berpartisipasi aktif dalam Program Kemitraan dan Bina Lingkungan (PKBL) dan Corporate Social Responsibility (CSR) seiring pertumbuhan perusahaan.

Fenomena yang dapat dilihat oleh PT Adhi Karya dari segi kepuasan pelanggan adalah bahwa hampir semua pelanggan yang sudah bekerja sama dengan PT Adhi Karya merasakan kepuasan dan senang atas kerja yang dilaksanakan oleh tim dari PT Adhi Karya ini dapat dilihat dari beberapa pelanggan yang menjalin hubungan kerja. Promosi berperan penting, karena dengan promosi yang handal dan menyakinkan akan mampu menarik minat pelanggan.

Tujuan penelitian ini adalah untuk menganalisis pengaruh kualitas layanan dan promosi terhadap kepuasan pelanggan PT. Adhi Karya,Tbk.

\section{LANDASAN TEORI}

\section{Kepuasan Pelanggan}

Bagi perusahaan yang bergerak dibidang produk dan jasa, kepuasan pelanggan adalah orientasi utama 
perusahaan. Pelanggan yang merasa puas dengan layanan yang diberikan perusahaan akan menjadi loyal dan melakukan pembelian ulang dimasa depan. Menurut Tjiptono (2008), "kepuasan atau ketidakpuasan pelanggan adalah respon pelanggan terhadap evolusi ketidaksesuaian atau diskonfirmasi yang dirasakan antara harapan sebelumnya (atas norma kinerja lainnya dan kinerja aktual produk yang dirasakan setelah pemakaiannya).

Menurut Kotler, (2008) "kepuasan adalah tingkat kepuasan seseorang setelah membandingkan kinerja atau hasil yang dirasakan dibandingkan dengan harapannya". Secara definitif dapat dikatakan bahwa kepuasan pelanggan (Swastha, 2008) adalah : "Suatu dorongan keinginan individu yang diarahkan pada tujuan untuk memperoleh kepuasan. Dalam hal ini kita perlu mengetahui bahwa suatu keinginan itu harus diciptakan atau didorong sebelum memenuhi motif. Sumber yang mendorong terciptanya suatu keinginan dapat berbeda dari diri orang itu sendiri atau berada pada lingkungannya. Kepuasan pelanggan dapat didefisniskan sebagai "evaluasi pasca konsumtif bahwa suatu alternatif yang dipilih setidaknya memenuhi atau melebihi harapan pelanggan" (Tjiptono, 2008). Menurut Sangadji dan Sopiah (2013), kepuasan pelanggan diartikan "sebagai suatu keadaan dimana harapan konsumen terhadap suatu produk sesuai dengan kenyataan yang diterima konsumen". Jadi, kepuasan merupakan fungsi dari persepsi atau kesan atas kinerja dan harapan. Kepuasan pelanggan merupakan faktor yang sangat penting bagi keberlangsungan dan perkembangan perusahaan. Saat ini kesadaran perusahaan akan pentingnya kepuasan konsumen semakin meningkat dan menjalankan strategi-strategi guna meningkatkan kepuasan konsumen.
Berdasarkan pengertian tersebut dapat disimpulkan kepuasan adalah perasaan senang atau kecewa seseorang yang muncul setelah membandingkan hasil produk yang dipikirkan terhadap kualitas yang diharapkan. jika hasil memenuhi harapan, pelanggan akan merasa puas. Sebaliknya, bila kualitas tidak memenuhi harapan, keinginan, dan kebutuhan pelanggan maka kepuasan tidak tercapai. Pelanggan yang tidak puas terhadap barang atau jasa yang dikonsumsinya akan mencari perusahaan lain yang mampu menyediakan kebutuhannya. Kepuasan pelanggan merupakan konsekuensi dari perbandingan yang dilakukan oleh pelanggan yang membandingkan antara tingkatan dari manfaat yang dirasakan terhadap manfaat yang diharapkan oleh pelanggan.

Menurut Irawan (2009), faktor faktor yang pendorong kepuasan pelanggan adalah sebagai berikut: 1) "Kualitas produk, pelanggan puas kalau setelah membeli dan menggunakan produk tersebut ternyata kualitas produknya baik. 2) Harga, untuk pelanggan yang sensitif, biasanya harga murah adalah sumber kepuasan yang penting karena pelanggan akan mendapatkan value for money yang tinggi. 3) Service quality, kepuasan terhadap kualitas pelayanan biasanya sulit ditiru. Kualitas layanan merupakan driver yang mempunyai banyak dimensi, salah satunya yang popular adalah SERVQUAL. 4) Emotional Factor, pelanggan akan merasa puas (bangga) karena adanya emosional value yang diberikan oleh brand dari produk tersebut. 5) Biaya dan kemudahan, pelanggan akan semakin puas apabila relatif mudah, nyaman dan efisien dalam mendapatkan produk atau pelayanan".

Menurut Kotler yang dikutip dari buku Total Quality Manajemen ada beberapa metode yang digunakan dalam 
melakukan pengukuran kepuasan pelanggan, diantaranya (Tjiptono, 2008): 1) "Sistem keluhan dan saran; Organisasi yang berpusat pelanggan (Customer Centered) memberikan kesempatan yang luas kepada para pelanggannya untuk menyampaikan saran dan keluhan.Informasi-informasi ini dapat memberikan ide-ide cemerlang bagi perusahaan dan memungkinkannya untuk bereaksi secara tanggap dan cepat untuk mengatasi masalah-masalah yang timbul. 2) Ghost Shopping; Salah satu cara untuk memperoleh gambaran mengenai kepuasan pelanggan adalah dengan mempekerjakan beberapa orang untuk berperan atau bersikap sebagai pembeli potensial, kemudian melaporkan temuantemuannya mengenai kekuatan dan kelemahan produk perusahaan dan pesaing berdasarkan pengalaman mereka dalam pembelian produk-produk tersebut. Selain itu para ghost shopper juga dapat mengamati cara penanganan setiap keluhan. 3) Lost Customer analysis; Perusahaan sebaiknya menghubungi para pelanggan yang telah berhenti membeli atau yang telah pindah pemasok agar dapat memahami mengapa hal itu terjadi. Bukan hanya exit interview saja yang perlu, tetapi pemantauan customer loss rate juga penting, peningkatan customer loss rate menunjukkan kegagalan perusahaan dalam memuaskan pelanggannya. 4). Survei kepuasan pelanggan; Umumnya penelitian mengenai kepuasan pelanggan dilakukan dengan penelitian survai, baik melalui pos, telepon, maupun wawancara langsung. Perusahaan akan memperoleh tanggapan dan umpan balik secara langsung dari pelanggan dan juga memberikan tanda (signal) positif bahwa perusahaan menaruh perhatian terhadap para pelanggannya".

Adapun indikator kepuasan pelanggan (Irawan, 2009), yaitu : 1) "Perasaan puas (dalam arti puas akan produk dan layanannya); yaitu ungkapan perasaan puas atau tidak puas dari pelanggan saat menerima pelayanan yang baik dan produk yang berkualitas dari perusahaan. 2) Selalu membeli produk; yaitu pelanggan akan tetap memakai dan terus membeli suatu produk apabila tercapainya harapan yang mereka inginkan. 3) Akan merekomendasikan kepada orang lain; yaitu pelanggan yang merasa puas setelah memakai suatu produk atau jasa akan menceritakannya kepada orang lain serta mampu menciptakan pelanggan baru bagi suatu perusahaan. 4) Terpenuhinya harapan pelanggan setelah membeli produk; yaitu sesuai atau tidaknya kualitas suatu produk atau jasa pasca pembelian suatu produk dengan harapan yang diinginkan pelanggan".

\section{Kualitas Layanan}

Kualitas layanan merupakan salah satu komponen penting yang perlu diperhatikan oleh para pelaku bisnis. Hal ini dikarenakan kualitas layanan memiliki pengaruh untuk mendatangkan konsumen baru dan dapat menghindari kemungkinan pelanggan lama untuk pindah ke perusahaan lain.

Menurut Tjiptono dan Chandra (2011), konsep kualitas dianggap sebagai "ukuran kesempurnaan sebuah produk atau jasa yang terdiri dari kualitas desain dan kualitas kesesuaian (conformance quality)". Kualitas desain merupakan fungsi secara spesifik dari sebuah produk atau jasa, kualitas kesesuaian adalah ukuran seberapa besar tingkat kesesuaian antara sebuah produk atau jasa dengan persyaratan atau spesifikasi kualitas yang ditetapkan sebelumnya. Maka dari itu yang dimaksud kualitas adalah apabila beberapa faktor dapat memenuhi harapan konsumen seperti pernyataan tentang kualitas oleh Goetsh dan Davis dalam Tjiptono dan Chandra (2011), "kondisi dinamis yang berhubungan dengan 
produk, jasa, sumber daya manusia, proses, dan lingkungan memenuhi atau melebihi harapan". Kualitas layanan adalah "keseluruhan ciri serta sifat dari suatu produk atau layanan yang berpengaruh pada kemampuannya untuk memuaskan kebutuhan yang dinyatakan" (Kotler dan Amstrong, 2015).

Menurut beberapa definisi tersebut dalam kata lain, kualitas adalah sebuah bentuk pengukuran terhadap suatu nilai layanan yang telah diterima oleh pelanggan dan kondisi yang dinamis suatu produk atau jasa dalam memenuhi harapan pelanggan. Menurut Lovelock dan Gummesson (2011) mendefinisikan bahwa service (pelayanan) adalah "sebuah bentuk jasa dimana para pelanggan atau konsumen dapat memperoleh manfaat melalui nilai jasa yang diharapkan". Konsep pemasaran jasa secara sederhana sebagai usaha untuk mempertemukan produk atau jasa yang dihasilkan oleh suatu perusahaan dengan calon pelanggan yang akan menggunakan jasa tersebut, oleh karena itu produk dan jasa yang dihasilkan oleh suatu atau perusahaan harus dapat memenuhi kebutuhan dan keinginan pelanggan.

Kotler dalam Tjiptono dan Chandra (2011), "setiap tindakan atau perbuatan yang dapat ditawarkan oleh suatu pihak kepada pihak lain yang pada dasarnya bersifat intangible (tidak berwujud fisik) dan tidak menghasilkan kepemilikian sesuatu". Menurut Tjiptono (2008), "sebagai layanan, istilah service menyiratkan segala sesuatu yang dilakukan pihak tertentu kepada pihak lain". Dari beberapa definisi tersebut, dapat disimpulkan bahwa layanan adalah sebuah aktifitas atau tindakan interaksi antara pihak pemberi dan pihak penerima layanan yang ditawarkan oleh pihak pemberi secara tidak berwujud sehingga tidak dapat dirasakan oleh fisik.
Menurut Parasuraman dalam Tjiptono (2008), terdapat faktor yang mempengaruhi kualitas sebuah layanan adalah "expected service (layanan yang diharapkan) dan perceived service (layanan yang diterima)". Jika layanan yang diterima sesuai bahkan dapat memenuhi apa yang diharapkan maka jasa dikatakan baik atau positif. Jika perceived service melebihi expected service, maka kualitas layanan dipersepsikan sebagai kualitas ideal. Sebaliknya apabila perceived service lebih jelek dibandingkan expected service, maka kualitas layanan dipersepsikan negatif atau buruk. Oleh sebab itu, baik tidaknya kualitas layanan terhantung pada kemampuan perusahaan dan stafnya memenuhi harapan pelanggan secara konsisten.

Menurut Parasuraman, Zeithaml, dan Berry dalam Tjiptono (2011) terdapat lima dimensi kualitas jasa yang dijadikan pedoman oleh pelanggan dalam menilai kualitas jasa, yaitu: 1) "Berwujud (Tangible); Penampilan fasilitas fisik, peralatan, dan personil. 2) Keandalan (Reliability); Kemampuan untuk melaksanakan jasa yang dijanjikan dengan tepat dan terpercaya. 3) Daya tanggap (Responsiveness); Kemauan untuk membantu pelanggan dan memberikan jasa dengan cepat atau tanggap. 4). Jaminan (Assurance); Pengetahuan dan kesopanan karyawan serta kemampuan mereka untuk menimbulkan kepercayaan dan keyakinan. 5) Empati (Emphaty); Syarat untuk peduli, memberi perhatian pribadi bagi pelanggan".

Menurut Tjiptono (2008), terdapat beberapa faktor yang perlu dipertimbangkan dalam meningkatkan kualitas layanan: 1) "Mengidentifikasi determinan utama kualitas layanan; Setiap penyedia layanan diwajibkan untuk menyampaikan layanan berkualitas terbaik kepada konsumen. Beberapa 
faktor yang menjadi penilaian konsumen seperti keamanan transaksi (pembayaran menggunakan kartu kredit atau debit), keamanan, ketepatan waktu, dan lainlain. Upaya ini dilakukan untuk membangun pandangan konsumen terhadap kualitas layanan yang telah diterima. Apabila terjadi kekurangan dalam beberapa faktor tersebut, perlu diperhatikan dan ditingkatkan. Sehingga akan terjadi penilaian yang lebih baik di mata pelanggan. 2) Mengelola ekspektasi pelanggan; Banyak perusahaan yang berusaha menarik perhatian pelanggan dengan berbagai cara sebagai salah satunya adalah melebih-lebihkan janji sehingga itu menjadi 'bumerang' untuk perusahaan apabila tidak dapat memenuhi apa yang telah dijanjikan. Karena semakin banyak janji yang diberikan, semakin besar pula ekspektasi pelanggan. Ada baiknya untuk lebih bijak dalam memberikan 'janji' kepada pelanggan. 3) Mengelola bukti kualitas layanan; Pengelolahan ini bertujuan untuk memperkuat penilaian pelanggan selama dan sesudah layanan disampaikan. Berbeda dengan produk yang bersifat tangible, sedangkan layanan merupakan kinerja, maka pelanggan cendrung memperhatikan "seperti apa layanan yang akan diberikan" dan "seperti apa layanan yang telah diterima". Sehingga dapat menciptakan persepsi tertentu terhadap penyedia layanan di mata konsumen. 4) Mendidik konsumen tentang layanan; Upaya mendidik layanan kepada konsumen bertujuan untuk mewujudkan proses penyampaian dan pengkonsumsian layanan secara efektif dan efisien. Pelanggan akan dapat mengambil keputusan pembelian secara lebih baik dan memahami perannya dalam proses penyampaian layanan. 5) Menumbuhkan budaya kualitas; Budaya kualitas dapat dikembangkan dalam sebuah perusahaan dengan diadakannya komitmen menyeluruh dari semua anggota organisasi dari yang teratas hingga terendah. Budaya kualitas terdiri dari filosofi, keyakinan, sikap, norma, nilai, tradisi, prosedur, dan harapan yang berkenaan dalam peningkatan kualitas. Beberapa faktor yang dapat menghambat namun dapat pula memperlancar pengembangan kualitas layanan. 6) Menciptakan automating quality; Otomatisasi berpotensi mengatasi masalah dalam hal kurangnya sumber daya manusia yang dimiliki perusahaan. Namun dibutuhkan perhatian dalam aspek-aspek sentuhan manusia (high touch) dan elemen-elemen yang memerlukan otomatisasi (high tech). Keseimbangan antara kedua hal tersebut sangat dibutuhkan untuk menghasilkan kesuksesan penyampaian layanan secara efektif dan efisien. 7) Menindaklanjuti layanan; Penindaklanjutan layanan diperlukan untuk memperbaiki aspekaspek layanan yang kurang memuaskan dan mempertahankan yang sudah baik. Dalam rangka ini, perusahaan perlu melakukan survey terhadap sebagian atau seluruh konsumen mengenai layanan yang telah diterima. Sehingga perusahaan dapat mengetahui tingkat kualitas layanan perusahaan di mata konsumen. 8) Mengembangkan sistem informasi kualitas layanan; Service quality information system adalah sistem yang digunakan oleh perusahaan dengan cara melakukan riset data. Data dapat berupa hasil dari masa lalu, kuantitaif dan kualitatif, internal dan eksternal, serta informasi mengenai perusahaan, pelanggan, dan pesaing. Bertujuan untuk memahami suara konsumen (consumen's voice) mengenai ekspektasi dan persepsi konsumen terhadap layanan yang diberikan perusahaan. Sehingga perusahaan dapat mengetahui kekuatan dan kelemahan perusahaan berdasarkan sudut pandang pelanggan".

\section{Promosi}


Pengertian promosi menurut Swastha (2008), promosi dipandang sebagai "arus informasi atau persuasi satu arah yang di buat untuk mempengaruhi seseorang atau organisasi kepada tindakan yang menciptakan pertukaran dalam pemasaran". Promosi merupakan usaha perusahaan untuk membujuk konsumen, menarik minat konsumen baru, dan memperkenalkan produk kepada pasar. Menurut Kismono (2001), definisi promosi adalah "usaha yang dilakukan pasar untuk mempengaruhi pihak lain agar berpartisipasi dalam kegiatan pertukaran". Promosi dapat berupa pemberian potongan harga, pemasangan iklan melalui media cetak maupun elektronik dan voucher. Bagi perusahaan yang baru berdiri kegiatan promosi menjadi sangat penting sebagai media untuk mengenalkan produk kepada pasar dan mendapatkan pasar. Menurut Tjiptono (2008) adalah "bentuk komunikasi pemasaran artinya aktivitas pemasaran yang berusahan menyebarkan informasi, mempengaruhi/membujuk dan atau mengingatkan pasar sasaran atas perusahaan dan produknya agar bersedia menerima, membeli dan loyal pada produk yang ditawarkan perusahaan yang bersangkutan". Lupiyoadi (2013) mendefinisikan pengertian promosi sebagai berikut, Promosi adalah "kegiatan yang dilakukan perusahaan untuk mengkomunikasikan manfaat produk dan sebagai alat untuk mempengaruhi konsumen dalam kegiatan pembelian atau penggunaan jasa sesuai dengan kebutuhan".

Berdasarkan definisi tersebut, dapat ditarik kesimpulannya, yaitu promosi adalah untuk memberitahukan, menginformasikan, menawarkan, membujuk, atau menyebarluaskan suatu produk atau jasa kepada calon konsumen dengan tujuan agar calon konsumen tersebut pada akhirnya dapat melakukan pembelian.
Perusahaan melakukan promosi untuk mencapai suatu tujuan tertentu, adapun tujuan promosi menurut Kismono (2001) adalah; 1) "Untuk menyebar luaskan informasi suatu produk kepada calon konsumen yang potensial. 2) Untuk mendapatkan konsumen baru dan untuk menjaga loyalitas pelanggan tersebut. 3) Untuk menaikkan penjualan serta laba/keuntungan. 4) Untuk membedakan dan mengunggulkan produknya dibandingkan dengan produk kompetitor. 5) Untuk branding atau membentuk citra produk di mata pelanggan sesuai dengan yang diinginkan. 6) Untuk merubah tingkah laku dan pendapat konsumen tentang suatu produk". Jadi secara keseluruhan tujuan utama promosi melakukan promosi adalah agar meningkatkan angka penjualan dan keuntungan usaha.

Melakukan kegiatan promosi terhadap beberapa variabel yang terkandung didalamnya, dan variabelvariabel tersebut harus dikombinasikan sesuai dengan kebutuhan dan kemampuan perusahaan. Kombinasi variabel-variabel promosi tersebut disebut dengan bauran promosi (promotional mix). Menurut Boone dan Kurtz (2008), promotional mix terdiri dari dua komponen yaitu aktivitasaktivitas penjualan pribadi dan penjualan non-pribadi yang di kombinasikan oleh pemasar untuk memenuhi kebutuhankebutuhan pelanggan yang menjadi target perusahaan dan untuk mengkombinasikan pesannya secara efekif dan efesien kepada mereka.

Promosi menurut Madura (2007) dapat dilakukan dengan: 1) "Penjualan pribadi (personal selling); Penjualan pribadi adalah presentasi penjulan secara personal yang di gunakan untuk mempengaruhi satu konsumen atau lebih. Penjualan ini memerlukan uapaya personal untuk mempengaruhi permintaan konsumen akan suatu produk. 
2) Penjualan non pribadi (non personal selling); Penjualan non pribadi atau tidak secara langsung dapat dilakukan dengan beberapa cara salah satunya promosi penjualan". Promosi penjualan adalah seragkaian aktivitas yang di maksudkan untuk mempengarhi konsumen. Promosi penjualan ini menjadi efektif untuk mendoromg konsumen untuk membeli produk tertentu.

Indikator promosi dapat digunakan perusahaan sebagai tolak ukur apakah pesan yang ingin disampaikan oleh perusahaan sampai pada konsumen yang dituju. Menurut Kotler dan Amstrong (2015), Ada lima indikator promosi utama yaitu: periklanan (advertising), promosi penjualan (sales promotion), hubungan masyarakat (public relation), penjualan pribadi (personal selling), dan pemasaran langsung (direct marketing). Definisi kelima indikator promosi utama tersebut sebagai berikut: 1) "Periklanan (advertising): bentuk presentasi dan promosi non pribadi tentang ide barang atau jasa yang dibayar oleh suatu sponsor tertentu. 2) Promosi penjualan (sales promotion): intensif jangka pendek untuk mendorong pembelian atau penjualan dari suatu produk atau jasa. 3) Hubungan masyarakat (public relation): membina hubungan baik dengan berbagai kelompok masyarakat yang berhubungan dengan perusahaan melalui publikasi yang mendukung, membina "citra perusahaan" yang baik, dan menangani cerita dan peristiwa yang merugikan perusahaan. 4) Penjualan pribadi (personal selling): penyajian pribadi oleh tenaga penjual perusahaan dengan tujuan penjual dan membina hubungan dengan pelanggan. 5) Pemasaran langsung (direct marketing): hubungan langsung dengan konsumen individual yang ditargetkan secara cermat untuk memperoleh respons segera dan membangun hubungan pelanggan yang langsung”.

\section{METODE PENELITIAN}

Penelitian ini adalah penelitian kuantitatif menggunakan data primer, uji validitas, uji reliabilitas, uji korelasi, uji regresi linier berganda, uji hipotesis dan uji t, serta analisa koefisien determinasi, dengan sampel sebanyak 80 responden pelanggan PT. Adhi Karya, Tbk melaui penyebaran kuesioner.

\section{HASIL PENELITIAN DAN PEMBAHASAN}

\section{Hasil Penelitian}

\section{Hasil uji validitas}

Pengujian validitas ini dilakukan untuk menguji apakah tiap butir pernyataan telah mewakili indikator yang akan diteliti, persyaratan minimum untuk dapat dikatakan valid adalah $\mathrm{r}$ sama dengan 0,30. Jadi, apabila korelasi antara butir-butir pernyataan dengan skor total kurang dari 0,30, maka butiran dalam instrumen tersebut dapat dikatakan tidak valid. Uji validitas dilakukan dengan melihat korelasi antara skor masingmasing butir pernyataan dengan skor total. Dari perhitungan koefisien korelasi skor tiap butir pernyataan dari 80 responden tentang kualitas layanan dengan jumlah 10 pernyataan; promosi 10 pernyataan, dan kepuasan pelanggan 8 pernyataan dengan total skor setiap responden diperoleh hasil valid dengan nilai r-hitung lebih besar dari r-krtitis (0.30).

\section{Hasil uji reliabilitas}

Pengujian reliabilitas ini dilakukan untuk menguji seberapa jauh hasil pengukuran yang dapat diandalkan secara konsisten. Hasil pengujian reliabilitas berikut, diketahui bahwa semua variabel mempunyai alpha di atas 0,6, artinya semua variabel dapat diandalkan. Berdasarkan tabel-1, menunjukkan bahwa cronbach alpha masing-masing 
variabel lebih dari 0,6, tampak bahwa seluruh variabel, yaitu kualitas layanan, promosi, dan kepuasan pelanggan dinyatakan reliabel.

Tabel 1: Hasil Uji Reliabilitas Variabel

\begin{tabular}{lcc}
\hline \multicolumn{1}{c}{ Variabel } & Cronbach's Alpha & Keterangan \\
\hline Kualitas Layanan & 0.724 & Reliabel \\
Promosi & 0.708 & Reliabel \\
Kepuasan Pelanggan & 0.718 & Reliabel \\
\hline Sumber: Data primer diolah, 2020 & &
\end{tabular}

\section{Analisis regresi linear berganda}

Tabel 2: Pengaruh Kualitas Layanan dan Promosi terhadap Kepuasan Pelanggan PT. Adhi Karya, Tbk

\begin{tabular}{|c|c|c|c|c|c|c|}
\hline \multirow[b]{2}{*}{ Variabel } & \multicolumn{6}{|c|}{ Parameter } \\
\hline & $\begin{array}{c}\text { Mult. } \\
\text { R }\end{array}$ & $\begin{array}{c}\mathbf{R} \\
\text { Square }\end{array}$ & $\begin{array}{l}\text { Kons } \\
\text { tanta }\end{array}$ & $\begin{array}{c}\text { Koefisien } \\
\text { Regresi }\end{array}$ & Sig. & $\alpha$ \\
\hline $\begin{array}{l}\text { Kualitas_Layanan } \\
\text { Promosi }\end{array}$ & 0,805 & 0,649 & 0,237 & $\begin{array}{l}0,203 \\
0,610\end{array}$ & $\begin{array}{l}0,050 \\
0,000\end{array}$ & 0,05 \\
\hline
\end{tabular}

\section{Pengujian Signifikan}

F hitung $>\mathrm{F}$ tabel $=71,056>3,115$

Sumber: Data primer diolah, 2020

Berdasarkan Tabel 2, nilai F-hitung sebesar 71,056 jika dibadingkan dengan F-tabel sebesar 3,115 yang didapat dari $(\mathrm{dk}=\mathrm{n}-\mathrm{k}-1=80-2-1=77)$, maka $\mathrm{F}-$ hitung lebih besar dari F-tabel (71,056 > $3,115)$, artinya secara bersama-sama kualitas layanan dan promosi berpengaruh positif dan signifikan pada tingkat nyata $99 \%$ terhadap kepuasan pelanggan PT. Adhi Karya, Tbk, atau dengan menggunakan $\mathrm{F}$ signifikan yaitu sebesar 0,000 lebih kecil dari tingkat kepercayaan 0,05 . Nilai koefisien determinasi $\left(\mathrm{R}^{2}\right)$ sebesar 0.649, artinya variabel kualitas layanan dan promosi memberikan kontribusi sebesar 64,9\% kepada variabel kepuasan pelanggan PT. Adhi Karya, Tbk, sedangkan sisanya sebesar $35,1 \%$ disumbangkan faktor lain yang tidak dibahas dalam penelitian ini.
Dengan demikian hipotesis pertama dapat diterima.

Persamaan regresi $\mathrm{Y}=0,237+0,203 \mathrm{X}_{1}+$ $0,610 \mathrm{X}_{2}$

Kualitas layanan dan promosi berpengaruh positif dan signifikan terhadap kepuasan pelanggan PT. Adhi Karya, Tbk pada tingkat nyata $99 \%$. Koefisien kualitas layanan sebesar 0,203 artinya jika ada peningkatan kualitas layanan, maka kepuasan pelanggan PT. Adhi Karya, Tbk akan meningkat atau sebaliknya dengan asumsi promosi tidak berubah. Koefisien promosi sebesar 0,610, artinya jika ada peningkatan promosi, maka kepuasan pelanggan PT. Adhi Karya, Tbk akan meningkat atau sebaliknya, dengan asumsi kualitas layanan tidak berubah. 


\section{Analisis regresi linear sederhana}

Tabel 3: Pengaruh Kualitas Layanan terhadap Kepuasan Pelanggan PT. Adhi Karya, Tbk

\begin{tabular}{llccccc}
\hline & \multicolumn{6}{c}{ Parameter } \\
\cline { 2 - 7 } Variabel & $\mathbf{R}$ & $\begin{array}{c}\text { R } \\
\text { Square }\end{array}$ & $\begin{array}{c}\text { Kons } \\
\text { tanta }\end{array}$ & $\begin{array}{c}\text { Koefisien } \\
\text { Regresi }\end{array}$ & Sig & $\boldsymbol{\alpha}$ \\
\hline Kualitas_Layanan & 0,711 & 0,505 & 6,259 & 0,657 & 0,000 & 0.05 \\
\hline Pengujian Signifikan & & & & & \\
\hline t hitung > t tabel = 8,919>1,991 & & & & \\
\hline Sumber: Data primer diolah, 2020 &
\end{tabular}

Persamaan Regresi $\mathrm{Y}=6,259+0,657 \mathrm{X}_{1}$

Berdasarkan Tabel 3, nilai koefisien determinasi $\left(\mathrm{R}^{2}\right)$ sebesar 0.505, artinya kualitas layanan memberikan kontribusi sebesar 50,5\% kepada kepuasan pelanggan PT. Adhi Karya, Tbk, sedangkan sisanya sebesar 49,5\% disumbangkan variabel lain yang tidak dianalisis, seperti promosi. Kualitas layanan berpengaruh positif terhadap kepuasan pelanggan PT. Adhi Karya, Tbk. Koefisien kualitas layanan sebesar 0,657, artinya jika ada peningkatan kualitas layanan, maka kepuasan pelanggan PT. Adhi Karya, Tbk akan meningkat atau sebaliknya.

Untuk menguji hubungan secara parsial variabel kualitas layanan terhadap kepuasan pelanggan PT. Adhi Karya, Tbk signifikan atau tidak, dilakukan pengujian t-hitung dibandingkan dengan t-tabel dengan tingkat $\alpha=0,05$, hasilnya adalah $\mathrm{t}$-tabel $=1,991$ yang dilihat dari tabel distribusi $\mathrm{t}$ (derajat kebebasan $=\mathrm{n}-2=$ 80-2 = 78), dengan uji dua pihak). Berdasarkan perhitungan tersebut dapat dinyatakan bahwa nilai t-hitung sebesar 8,919 dan t-tabel sebesar 1,991 atau $\mathrm{t}$ hitung > $\mathrm{t}$ tabel $(8,919>1,991)$, maka dapat diartikan bahwa kualitas layanan berpengaruh signifikan pada tingkat nyata $99 \%$ terhadap kepuasan pelanggan PT. Adhi Karya, Tbk. Dengan demikian hipotesis kedua dapat diterima.

Tabel 4: Pengaruh Promosi Terhadap Kepuasan Pelanggan PT. Adhi Karya, Tbk

\begin{tabular}{lcccccc}
\hline & \multicolumn{6}{c}{ Parameter } \\
\cline { 2 - 7 } Variabel & $\mathbf{R}$ & $\begin{array}{c}\mathbf{R} \\
\text { Square }\end{array}$ & $\begin{array}{c}\text { Kons } \\
\text { tanta }\end{array}$ & $\begin{array}{c}\text { Koefisien } \\
\text { Regresi }\end{array}$ & Sig & $\mathbf{A}$ \\
\hline Promosi & 0,794 & 0,630 & 1,641 & 0,781 & 0,000 & 0.05 \\
\hline Pengujian Signifikan \\
\hline
\end{tabular}


Sumber: Data primer diolah, 2020

Persamaan Regresi $\mathrm{Y}=1,641+0,781 \mathrm{X}_{2}$

Berdasarkan Tabel 4, nilai koefisien determinasi $\left(\mathrm{R}^{2}\right)$ sebesar 0.630, artinya promosi memberikan kontribusi sebesar 63,0\% kepada kepuasan pelanggan PT. Adhi Karya, Tbk, sedangkan sisanya sebesar $37,0 \%$ disumbangkan variabel lain yang tidak dianalisis, seperti kualitas layanan. Promosi berpengaruh positif terhadap kepuasan pelanggan PT. Adhi Karya, Tbk. Koefisien promosi sebesar 0,781, artinya jika ada peningkatan promosi, maka kepuasan pelanggan PT. Adhi Karya, Tbk akan meningkat atau sebaliknya.

Untuk menguji hubungan secara parsial variabel promosi terhadap kepuasan pelanggan PT. Adhi Karya, Tbk signifikan atau tidak, dilakukan pengujian t-hitung dibandingkan dengan t-tabel dengan tingkat $\alpha=0,05$, hasilnya adalah t-tabel $=1,991$ yang dilihat dari tabel distribusi $\mathrm{t}$ (derajat kebebasan $=\mathrm{n}-2=$ 80-2 = 78), dengan uji dua pihak). Berdasarkan perhitungan tersebut dapat dinyatakan bahwa nilai t-hitung sebesar 11,536 dan t-tabel sebesar 1,991 atau $\mathrm{t}$ hitung > t tabel $(11,536>1,991)$, maka dapat diartikan bahwa promosi berpengaruh signifikan pada tingkat nyata $99 \%$ terhadap kepuasan pelanggan PT. Adhi Karya, Tbk. Dengan demikian hipotesis ketiga dapat diterima.

\section{Pembahasan}

\section{Pengaruh Kualitas Layanan dan Promosi Terhadap Kepuasan Pelanggan PT. Adhi Karya, Tbk}

Peningkatan kualitas layanan dan promosi mendukung peningkatan kepuasan pelanggan PT. Adhi Karya, Tbk. Hasil penelitian ini sama dengan hasil penelitian yang dilakukan Arianto,
(2019), Fauzi, et al, (2019), Adriani \& Realize, (2018), dan Kasum dan Sularto, (2017) yang menyatakan bahwa kualitas layanan dan promosi berpengaruh terhadap kepuasan pelanggan.

\section{Pengaruh Kualitas Layanan Terhadap Kepuasan Pelanggan PT. Adhi Karya, Tbk}

Peningkatan kualitas layanan akan mendorong peningkatan kepuasan pelanggan. Hal ini dikarenakan bahwa perusahaan memiliki fasilitas yang berdaya tarik visual, menyediaan email untuk memandu pelanggan, menyiapkan produk sesuai yang dipesan, menyampaikan produk sesuai waktu yang dijanjikan, memberikan pelayanan yang cepat, kesiapan membantu permintaan pelanggan, menanamkan kepercayaan, memberikan kenyamanan, adanya perhatian secara individu paa pelanggan, dan menangani keluhan pelanggan dengan serius. Hasil penelitian ini sejalan dengan hasil penelitian yang dilakukan Kasum dan Sularto, (2017) dan Fauzi, et al, (2019). yang menyatakan bahwa kualitas layanan berpengaruh signifikan terhadap kepuasan pelanggan.

\section{Pengaruh Promosi Terhadap Kepuasan Pelanggan PT. Adhi Karya, Tbk}

Peningkatan promosi akan dapat mendorong peningkatan kepuasan pelanggan. Hal ini dikarenakan bahwa iklan produk yang ada di internet membuat daya tarik untuk melakukan pemesanan, tampilan iklan mudah diingat dalam memperkenalkan produk, pada saat tertentu perusahaan memberikan potongan harga, bagian pemasaran sering menawarkan produk secara langsung, berita mengenai produk dapat ditemukan 
diberbagai media, membina hubungan baik denga pelanggan, melakukan presentasi produk secara personel, bagian pemasaran ramah dalam memberikan informasi, pelanggan mendapatkan penawaran produk melalui telemarketing, dan informasi dan penjelasan yang diberikan menarik sehingga pelanggan tetap menggunakan produknya. Hasil penelitian ini sejalan dengan hasil penelitian yang dilakukan Arianto, (2019), dan Adriani dan Realize, (2018), yang menyatakan bahwa promosi berpengaruh signifikan terhadap kepuasan pelanggan. Dengan demikian hipotesis ketiga dapat diterima.

\section{KESIMPULAN DAN SARAN}

\section{Kesimpulan}

1. Kualitas layanan dan promosi secara bersama-sama mendorong peningkatan kepuasan pelanggan PT. Adhi Karya, Tbk.

2. Kualitas layanan mendorong peningkatan kepuasan pelanggan PT. Adhi Karya, Tbk.

3. Promosi mendorong peningkatan kepuasan pelanggan PT. Adhi Karya.

\section{Saran}

Berdasarkan hasil penelitian dan pembahasan, maka saran yang dapat disampaikan untuk perusahaan adalah:

1. Kualitas layanan yang diberikan oleh PT. Adhi Karya, Tbk sudah termasuk kategori baik. Namun demikian, perusahaan masih perlu menjaga konsistensi kualitas layanan dan lebih meningkatkan layanan agar pelanggan tidak menjadi bosan dan beralih kepada produk pesaing.

2. Promosi yang ditawarkan oleh PT. Adhi Karya, Tbk sudah cukup menarik perhatian pelanggan tetapi harus lebih ditingkatkan lagi frekuensi promosi yang diberikan, karena banyak pelanggan tidak sering memperhatikan kegiatan promosi yang dilakukan oleh PT. Adhi Karya, Tbk, yang sebenarnya memiliki program promosi yang menarik.

3. Ragam promosi yang diberikan PT. Adhi Karya, Tbk perlu diperluas lagi ruang lingkupnya agar dapat mencakup semua golongan pelanggan, karena selama ini PT. Adhi Karya, Tbk melakukan promosi dalam bentuk potongan harga.

4. Perlu dilakukan pengembangan penelitian mengenai kepuasan pelanggan dimasa yang akan datang, untuk penelitian selanjutnya agar lebih menambahkan variabel independen yang lain karena masih ada banyak variabel yang dapat mempengaruhi kepuasan pelanggan.

\section{DAFTAR PUSTAKA}

Adriani, Vesilia dan Realize. 2018. Pengaruh Kualitas Pelayanan dan Promosi Terhadap Kepuasan Pelanggan Pada PT. Stainlessindo Anugrah Karya Di Kota Batam. Jurnal Pundi, Vol. 02, No. 02, Juli 2018, hal. 169-180, ISSN: 23557052.

Arianto, Nurmin. 2019. Pengaruh Kualitas Pelayanan dan Promosi Terhadap Kepuasan Konsumen Pada Alfamart Roda Hias Serpong. Jurnal Ekonomi Efektif, Vol. 2, No. 1, Oktober 2019, hal. 153-160. ISSN: 2622-8882, E-ISSN: 26229935.

Boone, Louis E. Kurtz, David L. 2008. Pengantar Bisnis Kontemporer, Buku 1. Jakarta. Salemba Empat.

Fauzi, Azmi., Sarlo, Kurniawan dan Kenny. 2019. Pengaruh Promosi dan Kualitas Pelayanan terhadap 
Kepuasan Konsumen pada Pembelian Tiket Pesawat Garuda pada PT. Hamsa Tour and Travel (Studi kasus Pada Pembelian Tiket Medan- Jakarta). Jurnal Ekonomi \& Ekonomi Syariah, Vol. 2 No. 2, Juni 2019. E-ISSN: 2599-3410; PISSN: 2614-3259, hal. 378-391.

Goetsch, David L., and Davis B. Stanley. 2000. Quality Management: Introduction to Total Quality Management for Production, Processing, and Services, Third Edition, New Jersey, Prentice-Hall, Inc.

Irawan, Hendi. 2009. 10 Prinsip Kepuasan Pelanggan. Jakarta. Elex Media Komputindo.

Kasum, Sumi dan Sularto. 2017. Pengaruh Kualitas Pelayanan dan Promosi terhadap Kepuasan Pelanggan Grabbike di Jakarta Timur. Jurnal Administrasi dan Manajemen, Vol. 10, No. 2, Desember 2017, hal. 652-660, ISSN: $1693-6876$.

Kismono, Gugup. 2001. Pengantar Bisnis. Edisi I, Cetakan I. Yogyakarta. BPFE.

Kotler, Philip. 2008. Marketing Management, Milenium Edition, Jersey. Pearson Custom Publishing. Kotler, Philip \& Amstrong, Gary. 2015. Principles of Marketing, $15^{\text {th }}$
Edition, Pearson Education Limited.

Lovelock, C., dan Gummesson. 2011. Pemasaran Jasa. $7^{\text {th }}$. Jakarta. Erlangga.

Lupiyoadi, Rambat. 2013. Manajemen Pemasaran Jasa Berbasis Kompetensi. Edisi 3. Jakarta. Salemba Empat.

Madura. Jeff. 2007. Pengantar Bisnis. Edisi Empat. Terjemahan. Jakart. Salemba Empat.

Sangadji, Etta Mamang dan Sopiah. 2013. Perilaku Konsumen. Pendekatan Praktis Disertai Himpunan Jurnal Penelitian. Yogyakarta. Andi

Sugiyono. 2016. Statikstika untuk Penelitian. Bandung. Penerbit Alfabeta.

Swastha, Basu. 2008. Manejemen Pemasaran Modern. Edisi 2. Yogyakarta. Liberty.

Tjiptono, Fandy. 2008. Total Quality Management (TQM). Edisi 5. Yogyakarta. Andy Offset.

Tjiptono, Fandy dan Chandra, Gregorius. 2011. Service, Quality \& Satisfaction. Yogyakarta. Andi.

Zeithmal, Valarie A, A.Parasuraman \& Leonard L.Berry. 1990. Dilevery Quality Service. New York. The Free Press. 
